\title{
Improving Mathematical Critical Thinking and Habits Of Mind To Students in Elementary School
}

\author{
Maratun Nafiah', Zulela MS $^{2}$, Arita Marini ${ }^{3}$ \\ ${ }^{1}$ Universitas Negeri Jakarta, ${ }^{2}$ Universitas Negeri Jakarta, \\ ${ }^{3}$ Universitas Negeri Jakarta, Indonesia \\ e-mail:1mnafiah@unj.ac.id, ²ulelams@yahoo.co.id, 3aritamarini@unj.ac.id
}

\begin{abstract}
This study aims to improve mathematical critical thinking and habits of mind through the application the RAVE-CCC (Read, Attend, Visualize, Estimate, Choice, Calculate, Check) strategy for grade six students of Elementary School. This study uses Classroom Action Research method. The research design used Kemmis and Mc Taggart's model. The research data were collected using field note techniques, interviews, observations, and mathematical critical thinking test and habits of mind questionnaires. The results of this study indicate that, tests of students' mathematical critical thinking show increasing trend in each cycle. In the first cycle, the percentage of students who completed their scores with mathematical critical thinking skills was $70.83 \%$ which increases in the second cycle to 83.33\%. The percentage of teachers and students activity in each cycle has increased. In the first cycle, the percentage of achievement indicators was $78.57 \%$, in the second cycle, increased to $89.28 \%$. The active participation of all students in the first cycle was $76.19 \%$ and in the second cycle increased to $87.5 \%$. As for habits of mind, the percentage in the first cycle and second cycle also increased. In the first cycle the average percentage of students who showed a positive habits of mind was $66.66 \%$, in the second cycle increased to $83.33 \%$. Thus, it can be concluded that the adoption of the RAVE-CCC strategy can improve mathematical critical thinking and habits of mind.
\end{abstract}

Keywords: Mathematical critical thinking, students' habits of mind.

\section{Introduction}

In general, the way the society views the role of teachers and respect for teachers varies greatly depending on a number of factors, including personal expectations, individual experiences, and professional backgrounds. People want and expect different things from the teacher, meaning that teacher is considered to have different attributes, both in the classroom and in the community. According to Diaz, Pelletier, and Provenzo (2006: 203-205) teachers are considered as expert teachers, as learners of moral basics, teachers as art workers who have concern, teachers as authority figures, teachers as personal models, teachers as facilitator, and teacher as delegator. Teacher becomes an expert teacher, meaning that teacher is basically an information provider. Teacher as a learner of moral basics means that teaching is the first place for moral foundations in which teacher must be diligent in self-reflection and skillfulness. Teachers as caring art workers are expected to be sympathetic and friendly to students. In the model of teachers as authority figures, teachers set standards and ways of doing things; the material or subject matter being studied must be in accordance with the curriculum and needed by students. Teachers as personal models, involve teacher in learning through direct examples, teacher as an example means that they gives examples of good behavior. Teachers as facilitators act as providers of facilities so students can develop into adult humans. Teachers as delegators, in this model, teachers give assignments for students to complete. Good teachers learn to employ each model, using props that are appropriate to the material students studying. The best teachers try all of these models depending on the needs of students and the classrooms where they work.

The teacher is preparing the students facing the 21 st century life. The following is a list of the skills that a person needs to face the challenges of the 21st century: creativity, divergent thinking, critical thinking, team working (especially in heterogeneous groups), work autonomy, developed cognitive and interpersonal skills, social and civic competences, responsible national and global citizenship, consciousness of interdependence, acceptance and understanding of diversity, recognition and development of personal attributes, 
interactive use of tools, communication in mother tongue and foreign languages, mathematical and science competence, digital competence, sense of initiative and entrepreneurship, accountability, leadership, cultural awareness and expression, physical well - being (Chalkiadaki, 2018). Based on these opinions, creativity, critical thinking, team working (collaboration), or communication commonly referred to as the 4C. This competency, fourth in learning can be built through increased knowledge and the development of critical thinking, so will form habits of mind.

Habits of mind has an important role in the learning process and the development of the individual in helping to the problem. According to Ruseffendi (in Miliyawati, 2012) mathematics is formed as a result of human thought that relate to ideas, processes, and reasoning. In other words, mathematics as a science that develops critical thinking attitude, dynamic, and open cannot be separated with the reasoning. This is in line with the objectives of the curriculum 2013, i.e. prepare generation in order to have the ability to live as a private citizen and a productive, creative, innovative, and affective.

According to the Minister of Education and Culture Regulation No. 22 of 2016 concerning Basic and Secondary Education Process Standards the proces in teaching and learning should be interactive, inspirational, fun, challenging, motivating in order that the students can actively participate in class. In addition to this, education should give opportunities for the students' initiatives, creativity, and independence related to the students' talents, interests and physical and psychological development.

However, evidences observed at Kebon Kosong 16 Elementary School, Kemayoran District in Central Jakarta, the teachers do not use a variety of strategies specifically in teaching mathematics. In the preliminary observations of Grade 6, it was found that the teacher was not optimal in providing challenging problems. The questions given were routine with single answer. The teacher did not provide problem-based mathematical questions including non-routine questions improving high order thinking skills. Consequently, there is no space for the students to initiate, be creative and independent.

There are factors playing a role as contributors to the difficulties experienced by students in mathematics learning. These factors are weakness of knowledge about numbers, confusion of signs, various difficulties of arrangement, various difficulties of visual perception, lack of awareness about space, various difficulties of short and long term memory, speed of various processing difficulties, various language difficulties, cognitive style, and the students' anxiety towards mathematics. Difficulties due to the weakness of knowledge about numbers occur in students because of a less strong foundation, curriculum changes at school, the teacher not using contextual teaching, and teaching not starting from concrete to abstract level.

When students learn math subjects, examples of several theories will be more easily understood when obtained by carrying out an investigation. The students actively learn both phisically and mentally with hands on activity, ask questions, do activities through manipulating objects, collect data, and thinking of solving problems. Some findings can be found in the field, many students fail to learn the formal mathematical processes they are studying, for example in the concepts and operations of fraction numbers. They do not master the concept of fractions and operations so students find difficulty in working on fraction problems. It will be easier for students to understand when given problems that are close to their lives and carried out by investigating using teaching aids.

By knowing student learning difficulties, the teacher has a guide to teaching mathematics more effectively. If the teacher knows the various ways students acquire mathematical skills, this will help the teacher in developing teaching methods that are flexible and in accordance with varied learning methods. Teachers need to look for student learning difficulties in mathematics and need to know why students fail. This is a way for teachers to develop curricula that can overcome student gaps in the classroom and find problem solving strategies and skills as a means of increasing students' understanding of the mathematical concepts being studied.

Habits of mind also have an important role in the process of learning and individual development to help solve problems. Costa and Kallick (2008: 17) suggest thinking habits 
are "is a composite of many skills, attitudes, cues, past experiences, and proclivities. It means that we value one pattern of intellectual behaviors over another; therefore, it implies making choices about which patterns we should use at a certain time." This opinion implies that habits of mind are a combination of many skills, attitudes, cues, past experiences, and tendencies. This means that one must respect one pattern of intellectual behavior over another by making choices about a pattern that must be used at a certain time. This was also added by Costa in Hendriana and Soemarmo (2014: 93) interpreting habits of mind, namely strong dispositions and intelligent behavior. Teachers need to provide a paradigm of how students perceive themselves well because this is able to build thinking habits that make a person able to see themselves realistically. If this is successful, it can help students, especially those dealing with problem solving, and analyzing various problems in mathematics learning.

Burton in Koshy, Ernest and Casey (2000: 186) argue that various communication styles need to be used in mathematics learning. However, in this section, the discussion is concentrated on providing problem solving in mathematics and investigating how the teacher manages the giving of story questions in problem solving. As a result, students are encouraged to learn mathematics. Giving math problems based on these problems can encourage the development of mathematical critical thinking skills and the development of student thinking habits.

Gunawan in Suprijono (2016: 30 ) stated that critical thinking skills are the ability to think on a complex level and use the process of analysis and evaluation. John Dewey in Yaumi and Ibrahim (2013: 66-67) emphasizes that critical thinking is an active process, meaning to contrast a person's thinking process in general in receiving or obtaining information from other parties who tend to passively accept it. Critical thinking is the cognitive ability to express something with confidence because it relies on logical reasons and strong empirical evidence. Critical thinking is a process of systematic thinking in seeking the truth and building confidence in something that is factually and realistically reviewed and examined. The development of critical thinking skills will be achieved when given freedom and habitual thinking to students. Freedom of thought can be fulfilled if the teacher uses the right approach, gives students the flexibility to choose and find ways to solve problems.

One suitable strategy for solving problems is the RAVE-CCC (Read, Attend, Visualize, Estimate, Choice, Calculate, Check) strategy. The sequence in solving the problem is read - students read then attend - students pay attention to keywords, after the keyword is found then visualize - students try to visualize using pictures or diagrams, then estimate - students estimate the possibility of answers, the next step is choice - answer choices for used in solving problems, then calculating - calculate answers, and finally checking - check the answers.

This classroom action research is expected to contribute greatly in improving the learning process of mathematics in Grade 6 at Elementary School through the RAVE-CCC strategy in solving problems, to see whether there is an increase in mathematical critical thinking skills, and habits of mind. This research was conducted on the sixth-grade students of Kebon Kosong 16 State Elementary School, Kemayoran in Central Jakarta, a partner school for the Elementary School Teacher Education Department in State University of Jakarta.

\section{Method}

The research method used is the Classroom Action Research method which is participatory and collaborative and the research design used is Stephen Kemmis and Mc Taggart's model with stages: (a) planning, (b) acting and observing, (c) reflecting, and (d) replanning, (https://us.sagepub.com/en-us/nam/action-research/book236795). (Downloaded May 7, 2017). These stages can be described as follows. 


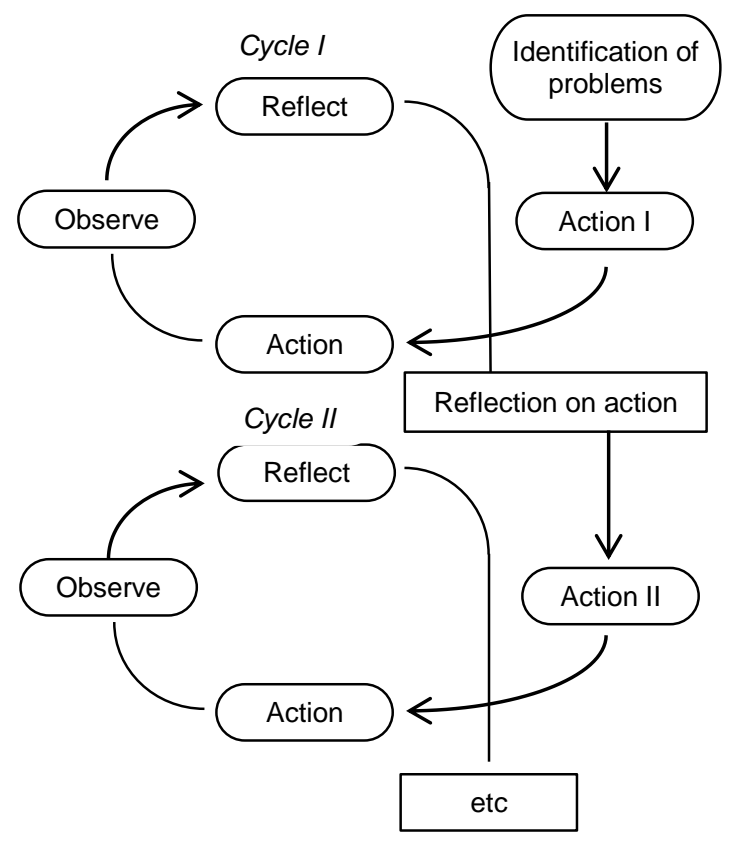

Figure 1. Kemmis and Mc.Taggart Action Research Model

The study was conducted on the sixth grade students of Kebon Kosong 16 State Elementary School, Kemayoran in Central Jakarta with 24 students. The research data were collected using field note techniques, interviews, observations, and filling out the research instruments in the form of tests of mathematical critical thinking skills and habits of mind questionnaires.

\section{Results and Discussion Cycle I}

The results of students 'mathematical critical thinking skills in the cycle $I$ is with the total value of the overall mathematical critical thinking abilities of students at 1686 and with the average score of students' mathematical critical thinking 70.25. Students who complete the score of mathematical critical thinking skills above the determined criteria are 17 of the 24 students with the percentage of student completeness achieved $70.83 \%$. The students who have not finished are 7 out of 24 students with the percentage of $29.16 \%$. These results have not reached the expected target, therefore it needs to be continued in the cycle II.

Observation of teacher and student activities using observation instruments with the 7 aspects observed in teacher activities and student activities, respectively. In the first cycle, the teacher activity scores obtained were 22 student with a percentage of achievement indicators of $78.57 \%$. The activities of all students in the first cycle get an overall score of 512 with a percentage of $76.19 \%$.

The use of the RAVE-CCC strategy is not only to improve mathematical critical thinking skills, but also to measure habits of mind using questionnaires with 50 statements. In the cycle I, the average percentage of students who show high habits of mind is 16 out of 24 students or with a percentage of $66.66 \%$. Students who show neutral habits of mind are 6 out of 24 students with a percentage of $25.00 \%$. The students who show low habits of mind are 4 out of 24 students or with the percentage of $16.66 \%$. These results have not reached the expected target because students who show high habits of mind have not reached $80.00 \%$ of all students. Therefore, research needs to be continued in the next cycle.

\section{Cycle II}


In the cycle II, the total score of students 'overall mathematical critical thinking abilities increased to 1956 with the average score of students' critical thinking skills 81.5. Students who complete the score of mathematical critical thinking skills above the determined target also increased by 20 out of 24 students with the percentage of students' completeness achieved at $83.33 \%$. The students who have not completed are 4 of the 24 students with the percentage of $16.66 \%$. These results have reached the expected target, that is the number of students who have completed the score above the determined target is more than $80 \%$.

The score of teacher activity in the cycle II increased from 22 to 25 with the achievement indicator percentage of $89.28 \%$. These results have reached the criteria for achieving teacher activity indicators which are above $80 \%$. In the cycle II, the activities of all students get an overall score of 588 with the percentage of $87.50 \%$. These results have reached the expected criteria with the achievement criteria of all student activity indicators above $80.00 \%$.

The average percentage of students in the cycle II showing a high habit of mind has increased to 20 out of 24 students or with the percentage of $83.33 \%$. Students who show neutral habits of mind have decreased to 3 out of 24 students with the percentage of $12.5 \%$. The students who show a low habit of mind also decreased to only 1 out of 24 students or with the percentage of $4.16 \%$. These results have reached the expected target because students who show positive habits of mind have exceeded $80 \%$ of all students.

\section{Mathematical Critical Thinking}

The results of tests of students' mathematical critical thinking ability show an increase in each cycle. At the pre-cycle time, students who completely get the score of mathematical critical thinking ability is 8 out of 24 students with the percentage of student completeness achieved at 33.33\%. The students who have not finished are 16 out of 24 students with the percentage of $66.66 \%$. In the cycle I, students who have completed the score of mathematical critical thinking ability are 17 of the 24 students with the percentage of students' completeness achieved at $70.83 \%$. The students who have not finished are 7 out of 24 students with the percentage of $29.16 \%$. There is a $37.50 \%$ increase in the percentage of completeness scores of students' mathematical critical thinking skills between pre-cycle and cycle I. These results have not reached the expected criteria, that is $80.00 \%$ of the total number of students. In the cycle II, after reflecting, students who got the score of mathematical critical thinking ability increased to 20 of the 24 students with the percentage of student completeness achieved at $83.33 \%$. As for students who have not completed as many as 4 of the 24 students with a percentage of $16.66 \%$. There is a $12.50 \%$ increase in the percentage of completeness of students' mathematical critical thinking skills between the first and second cycles. These results have exceeded the targeted criteria, namely $80.00 \%$ of the students. Below is a diagram of the increase of the results of students' mathematical critical thinking skills, pre cycle, cycle I, and cycle II.

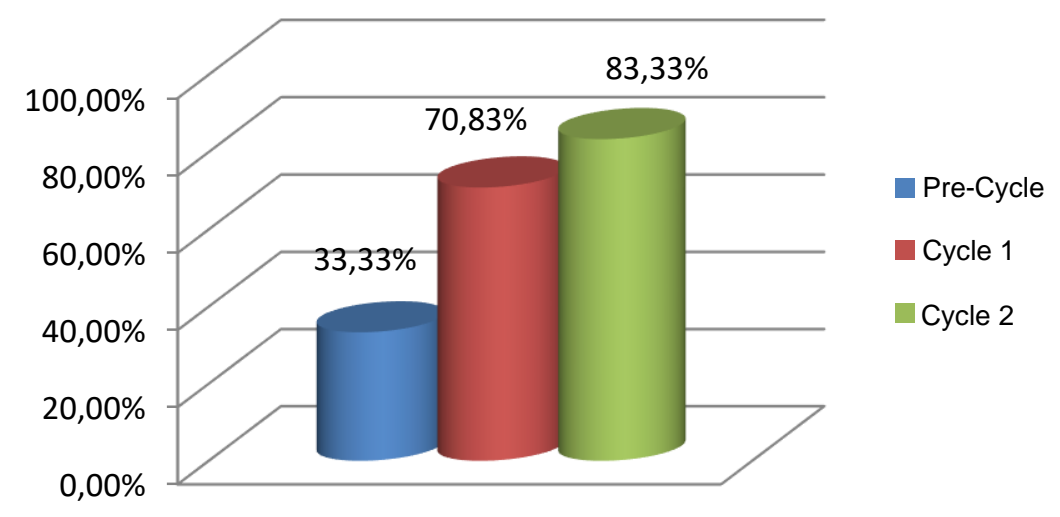


Figure 2. The Results Improvement Diagram of Students' Mathematical Critical Thinking Ability Pre-Cycle, Cycle 1, and Cycle 2

The total score of the overall mathematical critical thinking ability of students in precycle is 1145 with the average score of students' mathematical critical thinking ability of 47.71. In the cycle I, the total score of students 'overall critical thinking skills is 1686 with the average score of students' mathematical critical thinking skills of 70.25 . In the cycle II, the total score of the overall mathematical critical thinking ability of students increases to 1686 with the average score of students 'mathematical critical thinking skills by 1956 and the average score of students' mathematical critical thinking skills of 81.50 . There is an increase in the average score of students' mathematical critical thinking by 11.25.

\section{Teacher and Student Activity}

The activity of teachers and students in each cycle has increased. In the cycle I, the teacher activity scores obtained were 22 with the percentage of achievement indicators of $78.57 \%$. While the score of teacher activity in the cycle II increased to 25 with the indicator achievement percentage of $89.28 \%$. The teacher activities in the first and second cycle increased by $10.71 \%$.

The activities of all students in the cycle I get an overall score of 512 with the percentage of $76.19 \%$. As for the cycle II, the activity of all students has increased by getting an overall score of 588 with a percentage of $87.5 \%$. The activities of students in cycle I and II experienced an increase of $11.31 \%$.

The results of student and teacher activities in the cycle II have reached the determined criteria, that is above $80.00 \%$. The following is a diagram of the increase of teachers and students activity in cycles I and II.

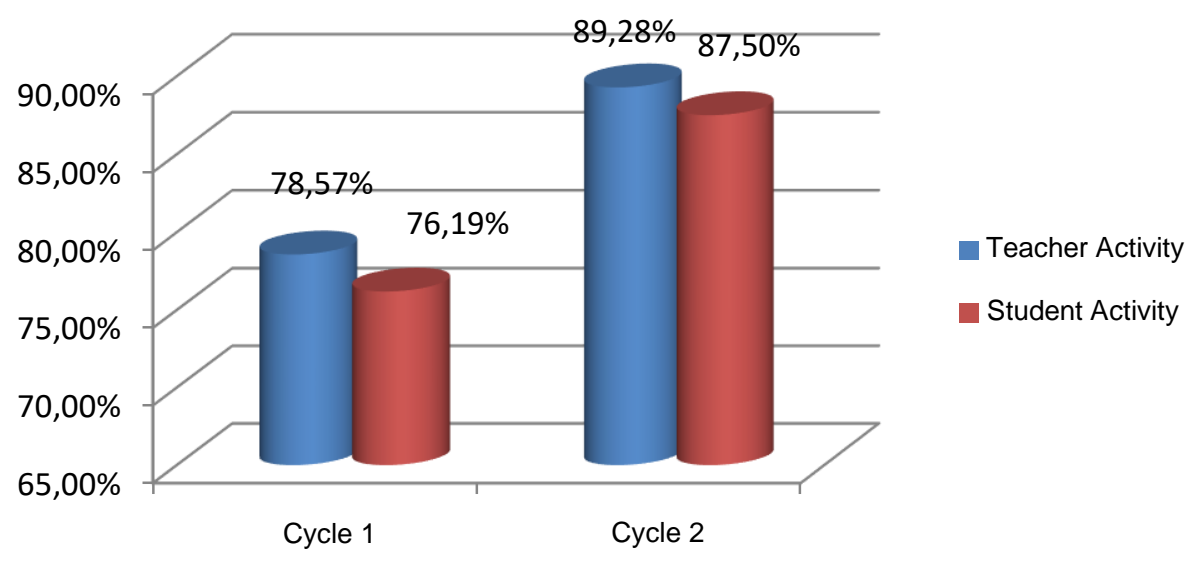

Figure 3. Teacher - Student Activity Improvement Diagram in Cycles 1 and 2 Diagram

\section{Student Habits of Mind}

There is an increase in students' thinking habits of mind in the cycles I and II. In the first cycle the average percentage of students who show high habits of mind is as many as 16 out of 24 students or with the percentage of $66.66 \%$. Students who show neutral habits of mind are 6 out of 24 students with the percentage of $25.00 \%$. The students who show low habits of mind are 4 out of 24 students or with a percentage of $16.66 \%$. These results have not reached the expected target because the number of students who show high habits of mind has not reached $80.00 \%$ of all students. Therefore, research needs to be continued in the next cycle. In the cycle II, students who show a high habit of mind experienced an increase of 20 out of 24 students or with the percentage of $83.33 \%$. Students who show neutral habits of mind decreased to 3 out of 24 students with a percentage of $12.5 \%$. The students who show low habits of mind also decreased to only 1 out of 24 students or with the percentage of $4.16 \%$. There is an increase in the percentage of students who show high 
habits of mind in the cycle I and II, which is equal to $16.67 \%$. The students who show neutral habits of mind in the cycle I and II show a decrease of $12.50 \%$. Furthermore, students who show low habits of mind in the cycle I and II also experienced a decrease of $12.50 \%$. Thus, these results have reached the expected target because students who show high habits of mind have exceeded $80.00 \%$ of all students. The following below is a diagram of the increase of students' thinking habits (Habits of Mind) in cycle I and cycle II.

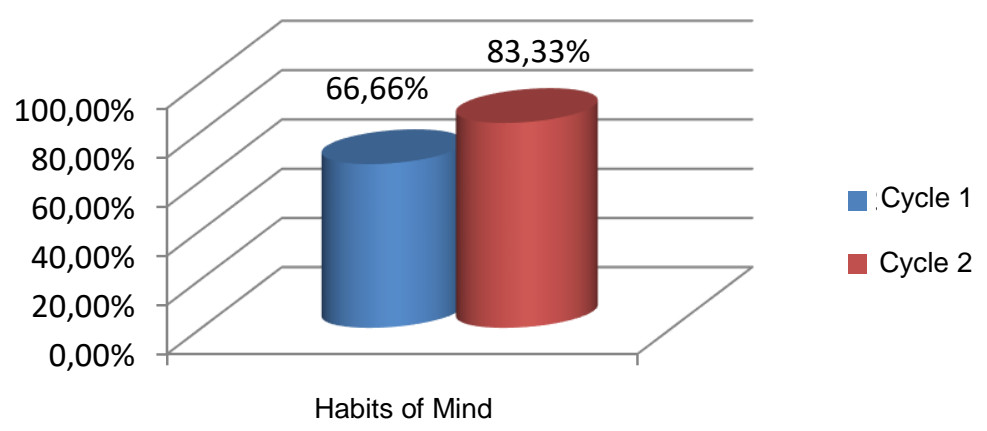

Figure 4. The Increase of the Student Thinking Habit (Habits of Mind) In Cycle 1 and Cycle 2 Diagram

Based on the results of the data obtained from the tests of mathematical critical thinking skills and observations of students' habits of mind, the implementation of the RAVECCC strategy can improve the mathematical critical thinking skills and habits of mind of the sixth grade students of Kebon Kosong 16 State Elementary School, Kemayoran in Central Jakarta. These results are also supported by research conducted by Eflina (2013) that the results of the study show: (1) the problem solving ability and mathematical logical thinking of students who learn to use the RAVE-CCC strategy is better than students who study normally; (2) the improvement of problem solving skills and mathematical logical thinking of students who learn to use the RAVE-CCC strategy is better than students who study normally. The results of a similar study conducted by Hasanah (2018) show that the results of the study were based on the first data analysis through one sample t-test. It is obtained that the significance value of the experimental group is $0,000<(\alpha) 0,025$ showing that $\mathrm{Ho}$ is rejected or there is an influence of the use of the RAVE-CCC NHT setting strategy on improving students' mathematical problem solving abilities.

The above findings relevant to research results Ioannis Papadopoulos (2018), to develop the thinking ideas of algebra in grade VI elementary school. It is very important for students to have a better experience in preparing them to know algebra formally. Puzzle Mobile seems to be an opportunity to show off the habit of thinking about a particular algebra understanding and supporting students in the transition from arithmetic to algebraic towards understanding. This collection includes some puzzles such as the balance of weight of objects that should be determined by the students. Arm/beams should be perfectly balanced to hang objects correctly. Each arm that balancing two sets of object is an equation. Data obtained from the class VI students who were asked to solve the balance reflects the existence of a confusing task, yet students persevere and this activity trained habit of thinking for them.

\section{Conclusion and Suggestion}

Based on the results and discussion of the above research, it can be summarized as follows:

1. The test results of students' mathematical critical thinking abilities show an increase in each cycle. At the pre-cycle time, the percentage of students who completely get the critical thinking ability score is $33.33 \%$. In the cycle I, the percentage of students who completely received their scores of mathematical critical thinking skills is 
$70.83 \%$. In cycle II, the percentage of student mathematical critical thinking abilities increased to $83.33 \%$. These results have exceeded the targeted criteria of $80.00 \%$.

2. There is an increase of the teacher and student activities in each cycle. In the cycle I, the percentage of achievement indicators is $78.57 \%$. The score of teacher activity in the cycle II has increased with the achievement indicator percentage of $89.28 \%$. The activities of all students in the cycle I is with the percentage of $76.19 \%$. In cycle II, the activities of all students increase with the percentage of $87.50 \%$. The results of student and teacher activities in the cycle II have reached the determined criteria which is above $80.00 \%$.

3. There is an increase of student thinking habits of mind in cycle I and cycle II. In cycle I, the average percentage of students who shows positive habits of mind is 16 out of 24 students or with the percentage of $66.66 \%$. In cycle II which showed a high habit of mind, there is an increase of 20 out of 24 students or with the percentage of $83.33 \%$. These results have reached the expected target because the number of students who show high habits of mind have exceeded $80.00 \%$ of all students.

\section{Reference}

Chalkiadaki, A. A Systematic Literature Review of $21^{\text {st }}$ Century Skills and Competencies in Primary Education. International Journal of Instruction, July 2018 Vol.11, No.3 e-ISSN: 1308-1470, p. 6 of 16. http://file.eric.ed.gov/fulltext/EJ1183407.pdf. Accessed 29 Januari 2019.

Costa, A. L. and Kallick, B. (2008). Learning and Leading with Habits of Mind: 16 Essential Characteristics for Success. Boston: ASCD.

Diaz, C. F.; Pelletier, Carol M.; Provenzo; Eugene F. Jr. (2006). Touch The Future Teach. Boston: Pearson.

Eflina. (2013). Penerapan Strategi RAVE-CCC Untuk Meningkatkan Kemampuan Pemecahan Masalah dan Berpikir Logis Matematis Siswa Sekolah Menengah Pertama. Thesis. Bandung: Universitas Pendidikan Indonesia.

Hasanah, I. U. (2018). "Pengaruh Strategi RAVE-CCC Setting Numbered Heads Together Terhadap Peningkatan Kemampuan Pemecahan Masalah Matematis Siswa: Penelitian Kuasi Eksperimen terhadap Siswa Kelas V pada Salah Satu SD di Kecamatan Ujungberung Kota Bandung. Thesis. Bandung: Universitas Pendidikan Indonesia.

Hendriana, H. dan Soemarmo, U. 2014. Penilaian Pembelajaran Matematika. Bandung: Refika Aditama.

Koshy, V; Ernest, P.; Casey, R. (2000). Mathematics for Primary Teaching. New York: Routledge.

Milliyawati, B. (2014). Urgensi Strategi Disposition Habits of Mind Matematis. Infinity Jurnal IImiah, 3 (2).

Ministry of Education and Culture. (2016). Process Standards of Basic and Middle Education. Regulation of Education and Culture Minister, No. 22 in 2016

Papadopoulos, I. Using Mobile Puzzles to Exhibit Certain Algebraic Habits of Mind and Demonstrate Symbol-Sense in Primary School Students. Journal of Mathematical Behavior. http://doi.org/10.1016/j.jmathb.2018.07.001.

Suprijono, A. (2016). Model-model Pembelajaran Emansipatoris. Yogyakarta: Pustaka Pelajar.

Yaumi, M \& Ibrahim, N. (2013). Pembelajaran Berbasis Masalah Kecerdasan Jamak (Multiple Intelligences). Jakarta: Kencana Prenandamedia Group. 